\title{
The analysis of Influence of Supervision and organizational climate to Teachers' Performance with Work Ethic as an Intervening Variable
}

\section{Jumawan}

Lecturer of Faculty of Economics, Bhayangkara Jakarta Raya University

Email: jumawan164@gmail.com

\begin{abstract}
The research objective to be achieved by the researcher is to discover whether there is a direct or indirect influence of supervision variables, organizational climate on teachers' performance with work ethic as an intervening variable. The population in this research is the teachers at the Masjid Meranti Foundation. In this research all populations are taken as samples, while the implemented data analyzing method was that of path-analysis. The findings of the study indicated that all the hypotheses were accepted, the supervision variable has a significant direct influence on work ethic; the organizational climate variable has a significant direct influence on work ethic; the supervision variable has a significant direct influence on consumer teacher performance; the organizational climate variable has a significant direct influence on teacher performance; work ethic variable has a significant direct influence on teacher performance; And the supervision variable and organizational climate indirectly have a significant effect on teacher performance through work ethic.
\end{abstract}

Keywords—supervision, organizational climate, work ethic, performance.

\section{INTRODUCTION}

Supervision is very important to be carried out by the organization in its operational activities to prevent the possibility of deviations by taking corrective actions against these deviations to achieve the goals set by the previous organization. Effective supervision provides aid for efforts to organize work in order for better implementation. The supervisory function is the last function of the management process. This function consists of the tasks of monitoring and evaluating organizational activities in order to achieve the target of the. In other words, the monitoring function assesses whether the plan that has been set in the planning function has been reached.

The Principal as leader certainly has the responsibility to manage the improvement program of education quality. Therefore, the Principal should be able to carry out effective supervision as mandated in the Minister of National Education Regulation Number 13 of 2007 concerning Standards of Principal. The importance of successful supervision to the improvement of education quality certainly adds to the demand for the implementation of supervisory programs prepared by the school principal.

Supervision by the school principal is as an effort of the school principal in guaranteeing that each teacher carries out their duties and functions efficiently, effectively, productively and responsibly. In addition, the supervision of the principal also functions as a tool for evaluating the performance of a teacher to determine the policy that will be taken by the Principal for the teacher concerned, such as promotion or transfer of duty (mutation).

Supervision activities at the Meranti Mosque Foundation in Central Jakarta are usually carried out without prior notification to the teachers so that the teachers feel trapped. Frequently, principals as supervisors keep a distance from the teachers. With these conditions, many teachers try to show their best performance only when observations take place therefore the teacher's actual performance cannot be measured.

In addition to the supervision carried out by the principal, the conditions of organizational climate in the school also affect work ethic and teacher performance. Principal leadership is expected to be able to create conducive organizational climate, in order to improve teacher performance. Gibson (2003) states that organizational climate is a series of environmental conditions that are felt directly and indirectly by employees. This illustrates organizational climate as a number of conditions or a series of conditions that can directly or indirectly, consciously or unconsciously, affect 
employees. The organizational climate that describes the atmosphere and working relations among educators, between educators and school principals, between educators and other education personnel and between services in their environment is a manifestation of a conducive work environment. This atmosphere is very much needed by educators and principals to carry out their work more effectively.

Negative climate manifests itself in the form of competitive, contradictory, invidious, opposed, ignorant, individualistic, selfish intercommunications. Negative climate can reduce teacher performance. Positive climate shows a close relationship with each other in many ways. There is mutual cooperation between them. All problems that arise are resolved together through deliberation. Positive climate shows that activities run harmoniously and in a peaceful, calm atmosphere that provides a sense of peace, comfort to the teachers. Positive climate in school forms if there is a good and harmonious relationship between the principal and teachers, teachers with teachers, teachers with administrative staffs, and students.

From observations, the organizational climate in the Central Jakarta Meranti Mosque Foundation appear quite conducive, but there are still some teachers who cannot be requested to work together in supporting teaching and learning activities, less accountable for teaching and learning activities which can be seen from those who only provide notes on the blackboard for students to write down or just work on the questions in the Student Activity Sheet, while the teacher doesn't do anything except to sit quietly at the front desk. The formation of a conducive climate for organizations can be a supporting factor for improving performance because comfort in work contains teachers to think calmly and will concentrate solely on the tasks being carried out.

Aside from a conducive school organizational climate, a high teacher work ethic is needed in improving his/her performance. A high teacher work ethic will determine the success of the effort and the learning process in school. An employee who has a high work ethic generally has a mental attitude in carrying out activities or work that is manifested in work behavior such as punctuality, responsibility, hard work, rationality and honesty. So, it is clear that the values contained in work ethic are very important in supporting the achievement of the level of employee performance. Teachers in the world of education have an important role in the success of learning. Teachers who have good personalities and characteristics are the main capital in achieving learning success. In order to optimize the quality of learning, teachers are required to be able to achieve their intended goals. One factor that needs to be considered in work ethic of teachers is the characteristic of someone who always prioritizes the quality of work to obtain maximum results. The work ethic possessed by the teacher will produce maximum quality of work.

In relation to the teacher's tasks in carrying out the daily learning process in school, the optimum results that can be achieved are in the form of a smooth learning process of students, and leading to high achievement or student learning outcomes, all of which is a reflection of the performance of a teacher. In carrying out his/her daily tasks, the performance of a teacher is reflected in his/her role and function in the learning process in the classroom or outside the classroom, namely as an educator, teacher, and trainer. In carrying out their roles and functions in the learning process in the classroom, performance of a teacher can be seen in the activities of planning, implementing, and evaluating the learning process in which the intensity is based on the moral and professional attitude of a teacher.

Based on these conditions, it is necessary to conduct a research entitled "Analysis of the Influence of Supervision and Organizational Climate to Teachers' Performance with Work Ethic as an Intervening Variable in the Central Jakarta Masjid Meranti Foundation". The research objective to be achieved by the researcher is to discover whether there is a direct or indirect influence of supervision variables, organizational climate on teachers' performance with work ethic as an intervening variable.

\section{THEORETICAL REVIEW}

\subsection{Supervision}

Supervision is one of the functions of organizational management. As one of the management functions, the notion of supervision has specifically developed. Arikunto and Yuliana (2008) state that supervision is a control that aims to measure the level of effectiveness of work activities that have been carried out and the level of efficiency of the use of other components in the management process. While according to Simbolon (2004) supervision is the process by which the leader would like to recognize the results of the implementation of the work carried out by subordinates in accordance with the plans, orders, objectives, policies that have been determined.

The supervision system will be effective if the monitoring system meets the principle of flexibility. In educational organizations, supervision techniques according to Purwanto (2005) consist of: 
- Individual techniques, comprising of: holding class visits, conducting observation visits, and guiding teachers related to curriculum implementation.

- Group techniques, comprising of: holding gatherings/meetings, group discussions, and in-service trainings.

Some previous studies related to the influence of supervision on work ethic, among others: Mardiana (2013), where supervision of the principal has a relationship with the teachers' work ethic; Sukarman, et al (2013), the results of the research indicate that clinical supervision can significantly improve the teachers' work ethic; Rahayu and Sutardji (2015), prove that the impact in the implementation of supervision by principals in improving the ethic of teachers' work is fair or moderate.

While previous research related to the influence of supervision on employee performance, among others: Suryani and Yarosi (2015), Amanda (2016), Rulandari (2017), Herdino and Andri (2017), Yousaf et.all (2018), Averus and Pitono (2018), the results of the research show that supervision has a significant effect on employee performance.

\subsection{Organizational Climate}

Kurt Lewin in the 1930s introduced the use of the term organizational climate. This term was then used by $\mathrm{R}$. Tagiuri and G. Litwin. According to Wirawan (2008), organizational climate is the perception of organizational members (individuals and groups) and those who are constantly in touch with the organization on what is regularly present or occurring in the organization's internal environment, which affects organizational attitudes and behavior and the performance of organizational members which will then determine the organization's performance. In line with the opinion of Lussier (2005), organizational climate is an employee's perception of the internal environment quality of the organization relatively felt by members of the organization which will then influence their subsequent behavior.

According to Litwin and Stringer (1968) there are 6 (six) dimensions of organizational climate indicators, namely:

1. Responsibility. Describes the feelings of employees of becoming leaders themselves and never ask for opinions in regards to their decisions from others. This includes independence in completing their work.

2. Standards. Measuring the feeling of pressure to improve performance and the degree of pride felt by the employees in conducting their work satisfactorily. This includes working conditions experienced by employees in the company.
3. Structure. Structure illustrates the feeling that employees are well organized and have a clear definition of their roles and responsibilities. This includes the position of employees in the company.

4. Recognition. The feeling of the employee being granted a decent reward after completing the work properly. This includes rewards or wages that employees receive after completing work.

5. Commitment. Describes the feeling of pride and commitment as members of the organization. This includes employee understanding of the goals to be achieved by the company.

6. Support. Describes the feeling of employees regarding trust and mutual support that apply in work groups. This includes relationships with other colleagues.

Several previous studies related to the influence of organizational climate on work ethic, among others: Ayuningtyas (2011); Fisandho (2011); and Alang (2014). The results of the research show that organizational climate has a significant effect on work ethic. Whereas previous studies related to the influence of organizational climate on employee performance, among others: Rahmadewi and Fauzan (2013); Karundeng (2013); Herman, et al (2014); Pasaribu and Kariono (2014); Setiawan (2015); Tantowi and Astuti (2016). The results of the research indicate that organizational climate has a significant effect on employee performance.

\subsection{Work Ethic}

High work ethic of a teacher will determine the success of the effort and the learning process in school. Atmodiwirio (2000) suggests that work ethic is a person's views and attitudes in assessing what work means as part of life in order to improve their lives. Specifically, the notion of work ethic is the basis for improving work performance/operation of each employee. In reference to this research, it is work ethic of the teacher in carrying out his duties at school. In this case work ethic of the teacher is seen in terms of carrying out the tasks skillfully.

According to Tasmara (2002), indicators of employees' work ethic can be influenced by several factors, including: a) On time, teachers who are on time are teachers who show an attitude of obedience to the provision of time. b) Responsibility, teachers who are responsible show the attitude of: (1) Completing tasks well and on time, (2) Obedient and compliant to school disciplines. c) Honest, honest teachers are transparent in providing value to students; And d) Confidence. Teachers who have the attitude of confidence in carrying out their tasks can be reflected through: (1) Confidence of their own abilities, (2) Optimistic. 
Several previous studies related to the influence of work ethics on performance, among others: Wahyudi et al (2013), Hadiansyah and Yanwar (2015), Yuliarti (2016), Bawelle and Sepang (2016), Salahudin et al (2016), and Sapada et al (2017) The results of the research show that work ethic has real influence on employee performance.

\subsection{Performance}

Performance in an organization is one element that cannot be separated in carrying out organizational tasks, either in the government or in private institutions. According to Mangkunegara (2008), employee performance is the quality and quality of work achieved by an employee in carrying out his/her duties in accordance with the responsibilities given to him. According to Sedarmayanti (2007), the notion of performance is the result of work that can be achieved by a person or group of people in an organization, in accordance with their respective authority and responsibility in an effort to achieve the objectives of the organization legally, not violating the law and in accordance with morals or ethics.

Therefore, performance or operation in the context of the teaching profession is an activity that includes learning planning, learning implementation/KBM, and evaluating or assessment of the learning result (MONE, 2008), which is the actualization of teacher competencies. The measurement results of the three activities illustrate the quantity and quality of the process and work results achieved by the teacher in teaching for a certain period of time. Thus, indicators of teacher teaching performance are: a. Learning planning. This stage is related to the teacher's ability to master teaching material. The ability of the teacher can be seen from the way or process of preparing the learning activities carried out by the teacher, namely developing syllabus and plan for the implementation of learning.

b. Implementation of learning. Learning activities in the classroom are the core of the implementation of education which is characterized by classroom management activities, media use and teaching methods.

c. Evaluation of learning results. At this stage a teacher is required to have the ability to determine approaches and methods of evaluation, preparation of evaluation materials, processing and the use of evaluation results.

\subsection{Research Conceptual Framework}

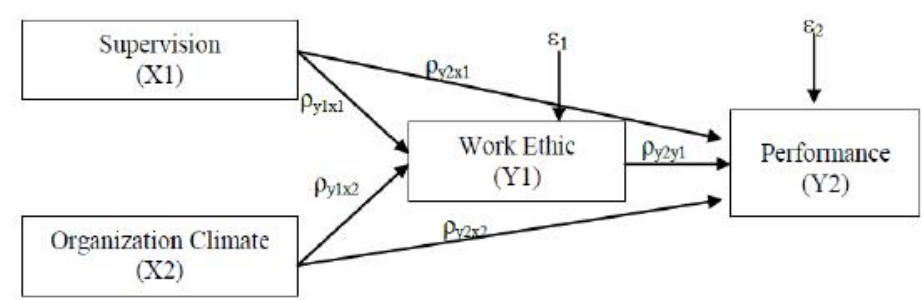

Fig.1: Research Model

\subsection{Research Hypothesis}

Based on the conceptual framework above the research hypothesis can be formulated as follows:

a. It is assumed that supervision variable has direct influence on work ethic.

b. It is assumed that organizational climate variable has direct influence on work ethic.

c. It is assumed that supervision variable has direct influence on teacher performance.

d. It is assumed that organizational climate variable has direct influence on teacher performance.

e. It is assumed that work ethic variable has direct influence on teacher performance.

f. It is assumed that supervision variables and organizational climate have an indirect influence on teacher performance through work ethic.

\section{RESEARCH METHOD}

The research method being used is a survey research, which focuses on relational research, i.e. researching the relationship of variables either directly or indirectly which places the emphasis on the research hypothesis. The population in this research is the teachers at the Masjid Meranti Foundation, both 39 permanent and non-permanent teachers. In this research all populations are taken as samples. Data sources are obtained from primary data and secondary data.

Based on the formulation of the problem, the frame of mind and the hypothesis proposed, the variables in the research are identified as follows:

1. Monitoring Variable (X1). Definition of supervision in general is an act of monitoring or examining the activities of an organization to ensure that the achievement of objectives is in accordance with the plan previously determined. The indicator of supervision assessment conducted by the principal in this research refers to the supervision technique (Purwanto, 2005), which consists of: individual technique and group technique.

2. Organizational Climate Variable (X2). Organizational climate is a concept that describes the internal environmental quality of the organization that affects 
the behavior of organizational members in carrying out their work. There are 6 (six) dimensions required bu the indicator of organizational climate based on the concept of Litwin and Stringer (1968), namely: responsibility, standards, structure, recognition, commitment, and support.

3. Work Ethics Variable (Y1). The definition of teacher work ethic in general is a characteristic that is shown by a teacher in regards to his/her enthusiasm, and performance in work (teaching), as well as attitudes and views on work. The indicator of work ethic in this research is taken from the theory of Tasmara (2002), namely: punctuality, responsibility, honesty, and confidence.

4. Teacher Performance Variable (Y2). Definition of performance is a quality and quantity result of work achieved by someone in carrying out their duties in accordance with the responsibilities granted to him. Teacher performance indicators in this research are taken from the Ministry of National Education (2008), namely: learning planning, implementation of learning, and evaluation of learning results.

Determination of score for each question against each statement uses a Likert scale which consists of 5 alternative choices, namely: strongly disagree (score 1) to strongly agree (score 5). After the questionnaire data is collected, the research materials are tested in the form of validity \& reliability tests, as well as classic assumption tests. If the quality of data requirements is met, analysis of the data will be performed by using the path analysis approach. Path analysis is used to determine the causal relationship, with the aim of explaining the direct and indirect consequences of a set of variables, which is as a causal variable and consequential variable.

\section{RESEARCH FINDINGS AND DISCUSSION}

\subsection{Research Finding}

The results of the validity test will show that the value of $r$ for each statement indicator of each variable has a value of $r \geq 0.30$, meaning that all items submitted are declared valid. While the reliability test results will show the value of Cronbach's alpha, each variable that is in accordance with the criteria has a value of $\geq 0.70$, meaning that each variable has a fairly good level of reliability. The results of the classic assumption test will show that the linear and normal data, and there is no multicollinearity between independent variables.

Hypothesis testing is done by using the Regression Weight test (loading factor), by looking at the significance of the probability value $(\mathrm{P})$, to which the cut-off value of $\mathrm{p}$ $<0.05$ will be considered significant. The hypothesis test results are as follows:
Table.1: Result of Hypothesis Testing

\begin{tabular}{|ll|rrrrr|}
\hline & & Estimate & S.E. & C.R. & P & Label \\
\hline Y1 <--- & X1 & .418 & .122 & 3.427 & .000 & par_1 \\
Y1 <--- & X2 & .672 & .122 & 5.493 & .000 & par_2 \\
Y2 $<---$ & Y1 & .330 & .156 & 2.117 & .034 & par_3 \\
Y2 $<---$ & X1 & .274 & .134 & 2.041 & .041 & par_4 \\
Y2 $<---$ & X2 & .523 & .157 & 3.323 & .000 & par_5 \\
\hline
\end{tabular}

Description: $C . R=t$ count $;$ Estimate $=$ Coefisient $; P=$ Probability

Based on the table above can be explained as follows:

1. Supervision (X1) has a significant direct influence on work ethic (Y1), with a probability value of 0,000 .

2. Organizational climate (X2) has a significant direct influence on work ethic (Y1), with a probability value of 0,000 .

3. Supervision (X1) has a significant direct influence on consumer teacher performance (Y2), with a probability value of 0.041 .

4. Organizational climate (X2) has a significant direct influence on teacher performance (Y2), with a probability value of 0,000 .

5. Work ethic (Y1) has a significant direct influence on teacher performance (Y2), with a probability value of 0.034 .

To see the direct and indirect influences between the research variables, path analysis technique is used. The following are the results of direct, indirect, and total effects that are standardized between endogenous and exogenous variables.

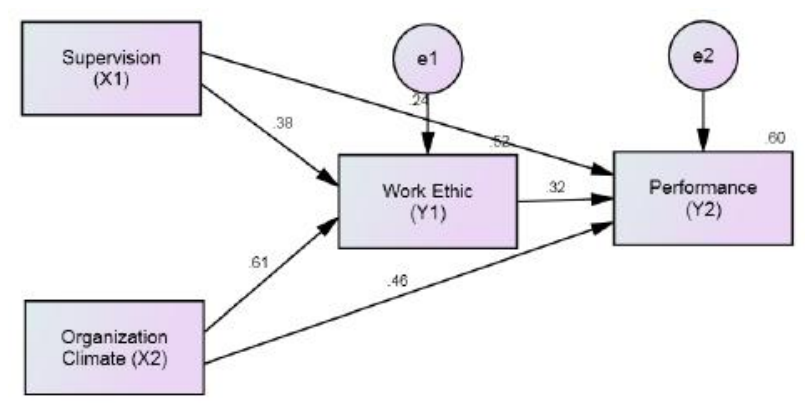

Fig.2: Result Path Analysis

Table 2. Standardized Direct, Indirect and Total Effects.

\begin{tabular}{|l|l|c|c|}
\hline \multicolumn{1}{|c|}{ Variable } & Effects & Count & Total Effect \\
\hline $\mathrm{X} 1 \rightarrow \mathrm{Y} 1$ & Direct & 0.383 & 0.383 \\
\hline $\mathrm{X} 2 \rightarrow \mathrm{Y} 1$ & Direct & 0.614 & 0.614 \\
\hline \multirow{2}{*}{$\mathrm{X} 1 \rightarrow \mathrm{Y} 2$} & Direct & 0.240 & \multirow{2}{*}{0.361} \\
\cline { 2 - 3 } & Indirect & 0.121 & \\
\hline
\end{tabular}




\begin{tabular}{|l|l|l|l|}
\hline \multirow{2}{*}{$\mathrm{X} 2 \rightarrow \mathrm{Y} 2$} & Direct & 0.457 & \multirow{2}{*}{0.651} \\
\cline { 2 - 3 } & Indirect & 0.194 & \\
\hline $\mathrm{Y} 1 \rightarrow \mathrm{Y} 2$ & Direct & 0.315 & 0.315 \\
\hline
\end{tabular}

Based on the images and tables above, it can be explained as follows:

a. Supervision (X1) has a direct influence on work ethic (Y1) by 0.383 .

b. Organizational climate (X2) has a direct influence on work ethic (Y1) by 0.614 .

c. Supervision $(\mathrm{X} 1)$ has a direct influence on teacher performance (Y2) by 0.240 and indirectly by 0.121 , so the total effect is 0.361 .

d. Organizational climate (X2) has a direct influence on teacher performance (Y2) by 0.457 and indirectly by 0.194 , so the total effect is 0.651 .

e. Work ethic variable (Y1) has a direct influence on teacher performance (Y2) by 0.315 .

The contribution of supervision variable (X1) and organizational climate (X2) to work ethic (Y1) is $52.4 \%$, while the contribution of supervision variable (X1), organizational climate (X2) and work ethic (Y1) to teacher performance is $60 \%$.

\subsection{Discussion}

1. First Hypothesis: It is assumed that supervision variable has direct influence on work ethic.

The results showed that the supervisory variable (X1) had a significant direct influence on work ethic (Y1), with an effect of 0.363 . This means that the better supervision carried out by the leadership at the Masjid Meranti Foundation, the better impact it will have on work ethic of the teachers at the foundation. Significance value by $0.000<0.05$, means that the first hypothesis which states that the supervisory variable has direct influence on work ethic, can be accepted. The results of this research are in line with previous studies conducted by Mardiana (2013); Sukarman, et al (2013); and Rahayu \& Sutardji (2015).

Supervision in the world of education is carried out with the intention of being able to find positive and negative matters in implementing education. So it's not solely looking for mere mistakes. There are at least several factors that can improve the teacher's work ethic, both internal and external factors. According to Mulyana (2006), there are several factors, among others: a) Encouragement to work, b) Responsibility for the task, c) Interest in the task, d) Award for the task, e) Opportunity to develop, f) Attention from the principal, g) Interpersonal relationships with teachers, h) Personal experience of a teacher, i) Can improve the teacher's work ethic, and j) Library services. Based on this explanation, it can be seen that the teacher must obtain attention or supervision from the principal so that the teacher can improve his/her work ethic and a teacher must have a good work ethic in order to achieve formal education. The principal is required to be able to lead while organizing and managing the implementation of teaching programs held at the school he leads. In this case, the principal must be able to be a good supervisor, because supervision is very important for schools to improve the quality of education (Arikunto, 2008).

2. Second Hypothesis: It is assumed that organizational climate variable has a direct influence on work ethic.

The results showed that organizational climate variable (X2) had a significant direct influence on work ethic (Y1), with an effect of 0.614 . This means that the better and conducive organizational climate in the Masjid Meranti Foundation, the better impact it will have on work ethic of the teachers at the foundation. Significance value of $0.000<0.05$, means that the second hypothesis which states that organizational climate variable has direct influence on work ethic can be accepted. The results of this research are in line with previous research conducted by Ayuningtyas (2011); Fisandho (2011); and Alang (2014). Based on the theory explained by Hoy and Miskel in Soetopo (2010), it states that if the organizational climate does not reflect a conducive situation, it will have an impact on the decline of individual and/or group incentives to provide trust and work effectively in running the organization. The basis of developing work ethic is a unity of interests that have mentioned many kinds of desires and needs of a person and group and to which these factors influence the success of a leader. According to Lubis in Sinamo (2002), good leaders must be able to foster a work ethic to develop values and something interesting in the organization. The leader must also be able to influence subordinates in carrying out daily tasks in order to achieve established organizational goals, with a maximum work ethic that will have a positive value on organizational success (Alang, 2014).

3. Third Hypothesis: It is assumed that supervision variable has direct influence on teacher performance.

The results showed that the supervisory variable (X1) had a significant direct influence on teacher performance (Y2), with a direct influence of 0.240 and an indirect influence of 0.121 . This means that the better supervision carried out by the leaders at the Meranti Mosque Foundation, the better impact it will 
have on the performance of teachers at the foundation. Significance value of $0.041<0.05$, means that the third hypothesis which states the supervisory variable has a direct influence on teacher performance can be accepted. The results of this research are in line with previous research conducted by Suryani and Yarosi (2015), Amanda (2016), Rulandari (2017), Herdino and Andri (2017), Yousaf et.al (2018), Averus and Pitono (2018).

One of the factors that support good performance of an employee is the supervision carried out by the leader to its employees in improving performance. With supervision, it is expected that employees can comply with the regulations set by the organization. Supervision is now part of an important factor in influencing employee performance in this case the teachers because it is a means of controlling or monitoring the activities within an organization. Through this supervision, employees can be monitored properly so that they can improve employee discipline in their work and have an impact on achieving maximum employee performance (Marpaung and Agustin, 2013).

4. Fourth Hypothesis: It is assumed that organizational climate variable has direct influence on teacher performance.

The results showed that the organizational climate variable (X2) had a significant direct influence on teacher performance (Y2), with a direct influence of 0.457 and an indirect influence of 0.194 . This means that the better and conducive organizational climate in the Meranti Mosque Foundation will have a good impact on the performance of teachers at the foundation. Significance value of $0.000<0.05$, means that the fourth hypothesis which states that organizational climate variable has direct influence on the performance of teachers can be accepted. The results of this research are in line with previous research conducted by Rahmadewi and Fauzan (2013); Karundeng (2013); Herman, et al (2014); Pasaribu and Kariono (2014); Setiawan (2015); Tantowi and Astuti (2016).

Siagian (2011) explains the organizational climate as a physical and non-physical work condition and the work environment should influence behavior and which can be a motivational factor that needs the attention of every leader in the organization. This means that organizational climate is a condition of the work environment, both material/physical and nonmaterial/non-physical, which can affect the behavior/performance of teachers within an organization (school). Organizational climate is important to create because it is a person's perception of what is given by the organization and is the basis for determining the behavior of the next member. Climate is determined by how well members are directed, built and valued by the organization. (Pasaribu and Kariono, 2014).

5. Fifth Hypothesis: It is assumed that work ethic variable has direct influence on teacher performance.

The results showed that the work ethic variable (Y1) had a significant direct influence on teacher performance (Y2), with a direct influence of 0.315 . This means that the better the work ethic of the teachers at the Meranti Mosque Foundation, the better impact it will have on the performance of teachers at the foundation. Significance value of $0.034<0.05$, means that the fifth hypothesis which states work ethic variable has a direct influence on teacher performance can be accepted. The results of this research are in line with previous research conducted by Wahyudi et al (2013), Hadiansyah and Yanwar (2015), Yuliarti (2016), Bawelle and Sepang (2016), Salahudin et al (2016), and Sapada et al (2017).

Anoraga (2001) states that success in work competition requires not only expertise and capability but also the need for dedication, hard work, and honesty in work. Someone who is successful must have a view and attitude that values work as a noble factor for human existence. Employees who have noble thoughts about their work can work sincerely. A view and attitude towards work is known as work ethic.

A high work ethic should be owned by every employee because every organization really needs hard work and high commitment from every employee, otherwise the organization will find it difficult to develop, and win the competition in seizing its market share. Every organization that always wants to advance will involve its members for their performance, in other words every organization must have work ethic. Individuals or community groups can be declared to have a high work ethic (Yuliarti, 2016).

6. Sixth: It is assumed that supervision variable and organizational climate have indirect influence on teacher performance through work ethic.

The results show that the first hypothesis until the fifth hypothesis are all accepted and proven to be true. This means that the sixth hypothesis which states the supervision variable and organizational climate have indirect influence on the performance of teachers through work ethic is a. The contribution of supervision variable (X1) and organizational climate 
(X2) to work ethic (Y1) is 52.4\%, while the contribution of supervision variable (X1), organizational climate $(\mathrm{X} 2)$ to teacher performance through work ethic (Y1) is $60 \%$.

\section{CONCLUSION}

Based on the results of the research and discussion it can be concluded that the supervision variable (X1) has a significant direct influence on work ethic (Y1). Similarly, the organizational climate variable (X2) has a significant direct influence on work ethic (Y1). The results also show that the supervisory variable (X1) has a significant direct influence on consumer teacher performance (Y2). Likewise, the organizational climate variable (X2) has a significant direct influence on teacher performance (Y2). Furthermore, work ethic variable (Y1) has a significant direct influence on teacher performance (Y2). And the supervision variable (X1) and organizational climate (X2) indirectly have a significant effect on teacher performance (Y2) through work ethic (Y1).

\section{REFERENCES}

[1] Alang, Syamsu. (2014). "Pengaruh Iklim Organisasi dan Kepemimpinan Kepala Sekolah Terdapat Etos Kerja Guru Serta Pegawai Pada SMP Negeri 120 Jakarta”. MAP. Volume 1 Nomor 1, Juli 2014. p: 1-89.

[2] Amanda, Regina. (2016). "Pengaruh Pengawasan Terhadap Kinerja Karyawan Melalui Disiplin Kerja Sebagai Variabel Intervening di PT Astra International Tbk Waru pada Bagian Part \& Accesories (Depo)". Jurnal Ilmu Manajemen. Volume 4 Nomor 4 - Jurusan Manajemen Fakultas Ekonomi Universitas Negeri Surabaya. p: 1-8.

[3] Amin Wahyudi., Tulus Haryono, Asri Laksmi Riyani, and Mugi Harsono. (2013). "The Impact of Work Ethics on Performance Using Job Satisfaction and Affective Commitment as Mediating Variables: Evidences from Lecturers in Central Java". Issues in Social and Environmental Accounting. Vol. 7, No. 3 September 2013. p: $165-184$.

[4] Arikunto, Suharsimi. (2006). Metode Penelitian Kualitatif. Jakarta: Bumi Aksara.

[5] Arikunto, Suharsimi dan Lia Yuliana. (2008). Manajemen Pendidikan. Yogyakarta: Aditya Media.

[6] Atmodiwirio, S. (2000). Manajemen Pendidikan Indonesia. Jakarta: PT Ardadizya Jaya.

[7] Averus, Ahmad., dan Andi Pitono. (2018). "Pengaruh Pengawasan Terhadap Kinerja Pegawai dalam Meningkatkan Pelayanan Kesehatan di Kota Palu Provinsi Sulawesi Tengah". Sosiohumaniora Jurnal Ilmu-ilmu Sosial dan Humaniora. Vol. 20, No, 1, Maret 2018. p: 1521.

[8] Ayuningtyas. Liya Febriyana. (2011). "Pengaruh Iklim Organisasi Terhadap Etos Kerja Pada Karyawan Bulu Mata di PT. Royal Korindah Purbalingga". Skripsi. Fakultas Psikologi. Universitas Muhammadiyah Purwokerto.
[9] Bawelle, Mouren., dan Jantje Sepang. (2016). "Pengaruh Etos Kerja, Gairah Kerja dan Disiplin Kerja Terhadap Kinerja Karyawan PT. BRI Cabang Tahuna". Jurnal EMBA. Vol. 4 No. 5, September 2016. p: 303-408.

[10] Davis dan Newstorm. (2000). Perilaku Dalam Organisasi. Jakarta: Erlangga.

[11] Davis, Keith dan John W. Newstrom. (1985). Perilaku Dalam Organisasi. Jakarta: Erlangga.

[12] Depdiknas. (2008). Penilaian Kinerja Guru. Jakarta: Depdiknas.

[13] Fisandho, Pieter Armand. (2011). "Pengaruh Iklim Organisasi Terhadap Etos Kerja Karyawan PD. Utama Semarang”. Skripsi. Fakultas Ekonomi Jurusan Manajemen. Universitas Katolik Soegijapranata Semarang.

[14] Hadiansyah, Andri., dan Rini Purnamasari Yanwar. (2015). "Pengaruh Etos Kerja Terhadap Kinerja Karyawan PT. AE". Jurnal AL-AZHAR INDONESIA SERI HUMANIORA. Vol. 3. No. 2, September 2015. p: 150158.

[15] Harahap, Sofyan. (2001). Sistem Pengawasan Manajemen. Jakarta: Penerbit Quantum.

[16] Henny. (2018). "Supervisi Kepala Sekolah dalam Meningkatkan Profesional Guru Pada SMA Methodist Kota Banda Aceh". Available at https://media.neliti.com/media/publications/242787supervisi-kepala-sekolah-dalam-meningkat-143d0db2.pdf (accesed 10 Desember 2018).

[17] Herdino, Dido., dan Seno Andri. (2017). "Pengaruh Pengawasan Terhadap Kinerja Karyawan Pada PT. Holcim Indonesia Cabang Perawang Kabupaten Siak”. Jom FISIP. Volume 4 No. 2 Oktober 2017. P:1-11.

[18] Herman, Djailani AR, dan Sakdiah Ibrahim. (2014). "Pengaruh Iklim Organisasi dan Kepuasan Kerja Terhadap Kinerja Guru". Jurnal Administrasi Pendidikan Pascasarjana Universitas Syiah Kuala. Volume 4, No. 2, November 2014. p: 157- 167.

[19] Karundeng, Christine Chely. (2013). "Pengaruh Iklim Organisasi Terhadap Kinerja Karyawan Pada PT. Taspen (Persero) Cabang Manado”. Jurnal Acta. Vol. 2 No. 3.

[20] Litwin Gh, \& Stringer Ra Jr. (1968). Motivation And Organizational Climate. Boston: Harvard University Press.

[21] Lussier, N Robert. (2005). Human Relations in OrganizationApplications and skill Building. New York: Mc Graw Hill.

[22] Mangkunegara, A.A. Anwar Prabu. (2008). Manajemen Sumber Daya Manusia. Cetakan kelima. Bandung: Penerbit PT. Remaja Rosdakarya.

[23] Mardiana. (2013). "Hubungan Supervisi Kepala Sekolah Dengan Etos Kerja Guru di Sekolah Menengah Pertama Negeri 29 Pekanbaru". Skripsi. Fakultas Tarbiyah dan Keguruan Universitas islam Negeri Sultan Syarif Kasim Riau Pekanbaru.

[24] Marpaung, Rio dan Agustin, Tri Dinda. (2013). "Pengaruh Pengawasan dan Disiplin Kerja Terhadap Kinerja Pegawai Kejaksaan Tinggi Riau". Jurnal Sosial Ekonomi Pembangunan. Vol.III (8). p: 141-164. 
[25] Mulyasa, E. (2006). Kurikulum Tingkat Satuan Pendidikan (KTSP). Bandung: Remaja RosdaKarya.

[26] Pasaribu, Safran Efendi., dan Kariono. (2014). "Pengaruh Iklim Organisasi Terhadap Kinerja Pegawai Pada Biro Rektor Universitas Muhammadiyah Tapanuli Selatan”. Jurnal Administrasi Publik. Vol. 2 No. 2. p: 177-195.

[27] Pasaribu, Safran Efendi., dan Kariono. (2014). "Pengaruh Iklim Organisasi Terhadap Kinerja Pegawai Pada Biro Rektor Universitas Muhammadiyah Tapanuli Selatan”. Jurnal Administrasi Publik. Vol. 2 No. 2. p: 177-195.

[28] Purwanto, Ngalim. (2005). Administrasi dan Supervisi Pendidikan. Edisi Revisi. Bandung: Remaja Rosda Karya.

[29] Rahayu, Retno Indah., dan Sutardji. (2016). "Supervisi Kepala Sekolah Dalam Peningkatan Etos Kerja Guru". Jurnal Magister. Vol. 01 Nomor 07. Juni 2015.

[30] Rahmadewi, Suci., dan Rizky Fauzan. (2013). "Pengaruh Iklim Organisasi dan Kepuasan Kerja Terhadap Kinerja Karyawan (Studi Pada Stasiun Meterologi Kelas II Supadio Pontianak)". Jurnal Eksos. November 2013, Th. IX, No. 3. p: $135-152$.

[31] Rulandari, Novianita. (2017). "The Effect of Supervision and Professionalism on Staff Performance at the Office of Social Affairs in East Jakarta Administrative City". International Journal of Humanities and Social Science. Vol. 7, No. 2; February 2017. p:184-192.

[32] Salahudin , Shahrul Nizam bin., Mohd Nur Ruzainy bin Alwia, Siti Sarah binti Baharuddina, and Siti Syafina binti Halimat. (2016). "The Relationship between Work Ethics and Job Perfomance". BE-ci 2016. 3rd International Conference on Business and Economics. 21 - 23 September, 2016. p: 465-471.

[33] Sapada, Achmad Faisal A., H. Basri Modding, Ahmad Gani, and Syamsu Nujum. (2017). "The Effect of Organizational Culture and Work Ethics on Job Satisfaction and Employees Performance". The International Journal of Engineering and Science (IJES). Volume 6. Issue 12. p: 28-36.

[34] Sedarmayanti. ( 2013). Manajemen Sumber Daya Manusia. Bandung: Refika.

[35] Setiawan, Kiki Cahaya. (2015). "Pengaruh Iklim Organisasi Terhadap Kinerja Karyawan Level Pelaksana di Divisi Operasi PT. Pusri Palembang”. Psikis Jurnal Psikologi Islami. Vol. 1 No. 1. p: 23-32.

[36] Sinamo, Jansen. (2002). Etos Kerja Profesional di Era Digital Global. Jakarta: Institut Darma Mahardika.

[37] Sobri, dkk. (2009). Pengelolaan Pendidikan. Yogyakarta: Multi Pressindo.

[38] Soetopo, Hendyat. (2010). Perilaku Organisasi: Teori dan Praktik Di Bidang Pendidikan. Bandung: PT. Remaja Rosdakarya.

[39] Sondang P. Siagian. (2011). Manajemen Sumber Daya Manusia. Jakarta: PT. Bumi Aksara.

[40] Sugiyono. (2009). Metode Penelitian Kuantitatif, Kualitatif dan R\&D. Bandung: Alfabeta.

[41] Sukarman, Ketut., Nyaman Dantes, dan Made Sutama. (2013). "Pengaruh Implementasi Supervisi Klinis Terhadap Etos Kerja dan Keterampilan Mengelola Pembelajaran
Pada Para Guru SD Se-Kecamatan Buleleng". e-Journal Program Pascasarjana Universitas Pendidikan Ganesha Program Studi Pendidikan Dasar. Volume 3 Tahun 2013.

[42] Suryani, Lilis., dan Yarosi. (2015). "Hubungan Pengawasan dan Kinerja Pegawai Pada Dinas Kebudayaan dan Pariwisata Kota Tangerang Selatan". Kreatif Jurnal Ilmiah Prodi Manajemen Universitas Pamulang. Vol. 2, No. 2, April 2015. p: 93-110.

[43] Tantowi, Ridwan., dan Hesti Widi Astuti. (2016). "Pengaruh Iklim Organisasi Terhadap Kinerja Karyawan Pada PT. Bank Danamon Simpan Pinjam Unit Metro". Jurnal Bisnis Darmajaya. Vol. 02 No. 02, Juli 2016. p: 134145.

[44] Tasmara, Toto. (2002). Membangun Etos Kerja Islam. Jakarta. Gema Insani Pers.

[45] Wirawan. (2008). Budaya dan Iklim Organisasi. Jakarta: Salemba Empat.

[46] Yousaf, Usman., Bushra Usman, and Talat Islam. (2018). "Effects of Supervision Practices of Principals on Work Performance and Growth of Primary School Teachers". Bulletin of Education and Research. April 2018, Vol. 40, No. 1. P: 285-298. 